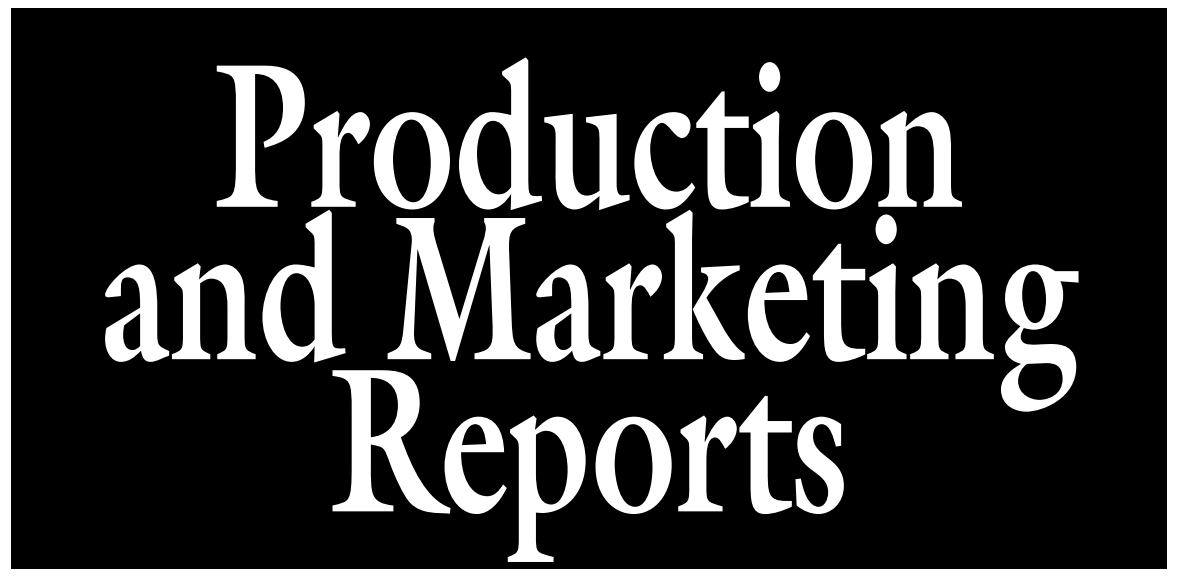

\title{
Consumer Perceptions of Landscape Plant Production Water Sources and Uses in the Landscape during Perceived and Real Drought
}

\author{
Melinda Knuth ${ }^{1}$, Bridget K. Behe ${ }^{2,4}$, Charles R. Hall ${ }^{1}$, \\ Patricia Huddleston ${ }^{3}$, and R. Thomas Fernandez ${ }^{2}$
}

ADDITIONAL INDEX wORDs. Cercis canadensis, cluster analysis, Heuchera americana, Koelventeria paniculata, Lavendula angustifolia, Rhus aromatica, online survey

SUMMARY. Water is becoming scarcer as world population increases and will be allocated among competing uses. Some of that water will go toward sustaining human life, but some will be needed to install and support landscape plants. Thus, future water resource availability may literally change the American landscape. Recent research suggests that consumers' attitudes and behavior toward potable water supplies have changed in other countries because of greater social awareness and increasingly widespread exposure to drought conditions. We conducted an online survey of 1543 U.S. consumers to assess their perceptions about landscape plants, the water source used to produce them, and plant water needs to become established in the landscape. Using two separate conjoint designs, we assessed their perceptions of both herbaceous and woody perennials. Consumers placed greater relative importance on water source in production over water use in the landscape for both herbaceous and woody perennials included in this study. They preferred (had a higher utility score for) fresh water over recycled water and least preferred a blend of fresh with recycled water for perennials and recycled water used for woody perennial production. In addition, the group that did not perceive a drought but experienced one placed a higher value (higher utility score) on nursery plants grown with fresh water compared with those which were actually not in drought and did not perceive one. Educational and promotional efforts may improve the perception of recycled water to increase the utility of that resource. Promoting the benefits of low water use plants in the landscape may also facilitate plant sales in times of adequate and low water periods.

A bout $40 \%$ to $70 \%$ of U.S. water is used in urban areas (Spinti et al., 2004; St. Hilaire et al., 2008 ) whereas $\approx 40 \%$ of food resources come from irrigated land (Somerville and Briscoe, 2001). Springer (2011) reported that the average U.S. household used $\approx 69$ gal of water per capita daily in 2006. Water is essential for life, including plant life, and water resources are likely to become scarcer as the world population increases
(Springer, 2011). Some of that water will be needed to install and support landscape plants, and future water shortages may literally change the American landscape if enough water is not allocated to ensure plant survival. This change may be in regionally native plants or overall drought-tolerant species.

Recent research suggests that consumers' attitudes and behavior toward potable water supplies have changed in other countries, in particular Australia, because of greater social awareness and increasingly widespread exposure to drought conditions (Beal et al., 2013). Changing water-use behavior involves a number of social and economic factors (Hurd, 2006; Syme et al., 1991). Outdoor water-use preferences are not only influenced by water prices and conservation motives, but also the time needed to implement conservation activities, knowledge on how to conserve water, and monetary restrictions. Influencing consumer attitudes, in turn, results in longer term responses for landscape water use, thereby potentially reducing future water demand (Hurd, 2006).

\section{Consumer attitudes in water use and "pro-environmental" behavior}

Consumers' attitudes regarding water conservation have become more positive and this change in attitudes is paralleled by small behavioral shifts in water usage (Beal et al., 2013). When given information about their water usage, households with inaccurate water assumptions made changes to their future water usage (Seyranian et al., 2015). Results from Seyranian et al. (2015) showed that $84 \%$ of households who received feedback on their water consumption and potential reduction methods reduced their total water consumption. Beal et al. (2013) examined perceived water usage as compared with actual water usage. Households that were informed about their water usage were more accurate in evaluating their water usage in their household. Other recent work suggests that consumers are more willing to purchase and pay more for plants grown using more environmentally friendly practices (Behe et al., 2013; Hall et al., 2010).

St. Hilaire et al. (2008) discovered that landscape water use could be

\begin{tabular}{llll}
\hline $\begin{array}{l}\text { Units } \\
\begin{array}{l}\text { To convert U.S. to SI, } \\
\text { multiply by }\end{array}\end{array}$ & U.S. unit & SI unit & $\begin{array}{l}\text { To convert SI to U.S., } \\
\text { multiply by }\end{array}$ \\
\hline $1,233.4819$ & acre- $\mathrm{ft}$ & $\mathrm{m}^{3}$ & 0.0008 \\
3.7854 & gal & $\mathrm{L}$ & 0.2642
\end{tabular}


majorly reduced in New Mexico communities when homeowners feared an imminent water shortage. They also found that educational programs regarding public water conservation influenced landscape choices from existing landscape plants to planting more water-conserving landscape plants. It would be noteworthy to understand how pervasive this perception is across the United States.

The findings of these studies suggest that people have a disinclination to engage in proenvironmental behaviors if they have a knowledge deficit. In other words, expertise about water consumptions matters. The key factor to explain this behavior is whether water knowledge includes actual water saving skills.

\section{Irrigation and water usage in the landscape}

In the residential context, indoor water usage remains relatively stable throughout the year and is largely attributed to household size and appliance efficiency (Gregory and Leo, 2003; Syme et al., 1991). However, outdoor water use is most often determined by seasonal need, garden type and importance, social norms, and size.

Caring for maintaining landscapes can have potential benefits to homeowners. Intensively cultivated landscapes meet esthetic and recreational priorities of homeowners, which are deeply ingrained in all lifestyles regardless of social status (Beal et al., 2013; Fan et al., 2017; Gregory and Leo, 2003; Springer, 2011; Syme et al., 2004). Plants in intensively managed landscapes fill a psychological need for homeowners, affecting their identity, status, and symbolic social competition in their respective communities (Seyranian et al., 2015). Homeowners who considered their gardens as positive influences on the resale value of their

\footnotetext{
Funding for this study was provided by USDA SCRI Clean Wate ${ }^{3}$ - Reduce, Remediate, Recycle Grant Number 2014-51181-22372; USDA NIFA Hatch Projects MICL 02085, MICL 1011569, and TEX01-7051; Michigan State University AgBioResearch, and MSU Project GREEN and Texas A\&M AgriLife Research.

${ }^{1}$ Department of Horticultural Sciences, Texas A\&M University, 202 Horticulture/Forest Science Building, 2133 TAMU, College Station, TX 77843-2133

${ }^{2}$ Department of Horticulture, Michigan State University, 1066 Bogue Street, East Lansing, MI 48824

${ }^{3}$ Department of Advertising and Public Relations, Michigan State University, East Lansing, MI 48824

${ }^{4}$ Corresponding author. E-mail: behe@msu.edu.

https://doi.org/10.21273/HORTTECH03893-17
}

house used more water annually, as did people who spent more time outdoors (Syme et al., 2004). Increased knowledge and education seem to be directly linked to conservation adoption strategies such as turning off the tap when washing dishes or buying plants that need less water (Gilg and Barr, 2006; St. Hilaire et al., 2008). Householders using less water had a greater concern for conservation issues, local concerns, and future preservation of water resources (Gregory and Leo, 2003).

Higher water usage is associated with lifestyle preferences for large gardens, large lawns, lush/vegetative home environments, and high enjoyment of gardening. Jorgensen et al. (2009) and Syme et al. (2004) both found that garden recreation, garden value, how much people spend on their gardens, and attitudes toward the price of water all affect water usage behavior. Hayden et al. (2015) reported that when given the choice between three different landscapes ranked as high managed (A), moderately managed (B), and low managed (C); landscape $\mathrm{B}$ was the most aesthetically preferred, while landscape $\mathrm{C}$ was found to be the "most ecologically/environmentally friendly." In this context, the term "managed" means the level of input, resources, and time required to maintain the landscape. Hayden et al. (2015) also observed that $50 \%$ of respondents did not find a time-intensive landscape to be unappealing because they enjoyed gardening and yard work. Although $82 \%$ of respondents recognized that the highly managed landscape (A) required the most water to maintain and the low managed landscape $(\mathrm{C})$ required the least, this still did not persuade respondents to select the low-managed landscape $(\mathrm{C})$ as most preferred when only considering water use. This may indicate a barrier in knowledge and potential deterrent behavior in homeowners, presenting a much needed educational opportunity.

The use of water-conserving plants and suitable eco-friendly plants has been promoted as a water conservation strategy for homeowners. A better understanding of consumer perceptions of water source and landscape plant water use would help plant sellers and policymakers know what consumers are currently thinking and what motivates their water-use behavior before additional reductions in water use change the industry in unintended ways.

\section{Water sources}

Recycled wastewater, from washing machines, bathtubs, showers, and sinks but not toilets, constitutes $\approx 60 \%$ of the total wastewater from households. This can equate to $\approx 30,000 \mathrm{gal}$ of gray water per year for a family of four people (Al-Jayyousi, 2003; Cabrera et al., 2013). Potentially, if gray water is treated correctly, or is used on a suitable plant community to accommodate (compounds) present, it can result in groundwater recharge, and may play a substantial role in the reuse and total reduction of water usage by households (Al-Jayyousi, 2003; Eriksson et al., 2002). Not much data are available regarding U.S. recycled water usage, but California's Department of Water Resources (2004) released a short report reporting the usage of recycled water during the year 2002 . About 525,000 acre-ft of recycled water was reused in California. Agricultural irrigation used $\approx 46 \%$ of the total recycled water available annually, followed by landscape irrigation (21\%), and lastly, groundwater recharge (14\%) (California Department of Water Resources, 2004).

However, fresh water has been traditionally used for all indoor and outdoor purposes because of the lack of information and fear of detrimental contaminants from recycled water (St. Hilaire et al., 2008). St. Hilaire et al. (2008) stated, "[the] possible risks include human health-related problems, soil salinization and plant damage, leached nutrients as environmental contaminants, and the loss in aesthetic value of water features" if humans come into direct contact with gray water. Thus, Municipalities in Orange County, CA, require irrigation with gray water to occur at night to minimize human exposure (Western Municipal Water District, 2017). By contrast, Yanko (1992) could not find any detectable hazards associated with reused water when used to irrigate parks, urban landscapes, agricultural crops, or groundwater recharge in California.

Research has not documented the overall perception of water sources and uses by plants in the landscape throughout the United States. For example, attitudes and behaviors in areas prone to drought situations may be different from areas with sporadic or no drought conditions. In turn, 
the attitudes and behaviors of consumers will likely influence their plant purchases and the maintenance of plants already in their landscape. Our objective was to assess the attitudes and behaviors of a large sample of U.S. consumers to better inform green industry firms about potential future consequences to the industry. More specifically, we sought to identify consumer preferences for the water source and amount used during the production of plants vs. their water use in the landscape. Furthermore, we wanted to assess the impact of real and perceived drought on the attitudes and behavior of consumers.

\section{Materials and methods}

We developed an online survey following widely accepted market research protocols to ensure greater degree of accuracy and speed, while reducing human error and survey expenses (Cobanoglu et al., 2001; Dillman et al., 2009; McCullough, 1998). The use of online surveys can have disadvantages, especially if the sampling database contains the same panelist under different accounts. To mitigate this concern, we contracted with Global Market Insite (Washington, DC), which maintains a panel of several million people and has control mechanisms in place to eliminate duplicate panelists. Global Market Insite developed a random sample from individuals $\geq 18$ years of age and distributed invitations to the sample frame to participate in the survey. Both the survey instrument and methodology of data collection were approved by the university committee involving research with human subjects (Michigan State University IRB\# x 16-1053e Category: Exempt 2 ).

Consumers buy products they value, and researchers usually estimate this value based on attributes that comprise the product. Conjoint analysis is one mechanism that allows researchers to estimate how consumers value each attribute. It is a widely used method to characterize consumer preferences and the relative importance of product attributes. Conjoint analysis has been used to understand the consumers' purchase drivers and willingness to pay for attributes and attribute levels for a wide range of horticultural products, including Christmas trees (Behe et al., 2005b), landscapes (Behe et al., 2005a), biodegradable pots (Yue et al., 2010), mixed flowering annual containers (Mason et al., 2008), impatiens (Impatiens walleriana) alternatives (Getter and Behe, 2013), sustainable/ eco-friendly plant production (Behe et al., 2010, 2013; Rihn et al., 2015, 2016), and vegetable and herb plant brands (Behe et al., 2016). By assessing consumer's valuation on each product attribute, we can determine the related level of part-worth utility associated with each attribute, as well as the product as a whole.

For this study, we developed two separate conjoint designs: one for woody perennials and one for herbaceous perennials. We used a combination of product attributes and levels that represented three plant types (genera), three price levels, three water sources during production (grown in the nursery with fresh water, grown in the nursery with recycled water, grown in the nursery with a blend of fresh and recycled water), and two landscape water-use levels (requires irrigation in the landscape, but only for the first season to help the plant to become established; requires irrigation in the landscape for most seasons after establishment) for a $3 \times 3 \times 3 \times 2$ factorial design. The landscape water use categories were derived from the University of California-Davis Water Use Classification of Landscape Species IV (Costello and Jones, 2014). These categories were based on the rate of evapotranspiration expressed as a percentage in reference to evapotranspiration rates in maintained, wellirrigated tall fescue (Festuca arundinacea) turf. Plants classified in the "high" category need frequent irrigation during normal rainfall years, plants classified in the "low" category need minimal irrigation during years of normal rainfall, and plants classified in the "very low" category need no irrigation except during years below average rainfall (Costello and Jones, 2014). However, all six plants used in this study appear on the list for low water use plants. The herbaceous perennial plants included were coral bells (Heuchera americana), 'Munstead' english lavender (Lavendula angustifolia), and 'Homestead Purple' perennial verbena (Verbena sp.) with prices of $\$ 6.99, \$ 9.99$, and $\$ 12.99$, per container. The woody perennials included were goldenrain tree (Koelreuteria paniculata), 'Gro Low' fragrant sumac (Rhus aromatica), and redbud
(Cercis canadensis) with prices of $\$ 19.99, \$ 29.99$, and \$39.99, per container. Price points were established through conversations with industry practitioners. Although all 54 combinations could have been presented to subjects, we developed two partial factorial designs of nine combinations using SPSS software (version 22; IBM, Armonk, NY). This was performed to retain the ability to assess all attributes in the complete design but reduce the time required, and the resulting potential, for subject fatigue (Chrzan and Orme, 2000). Each digital image consisted of a picture of the plant in a container photographed against a black background with the accompanying information above the image (Fig. 1).

The survey comprised five parts: 1) types and amounts of plants purchased, 2) conjoint questions for both herbaceous perennials and woody perennials, 3) water conservation knowledge and behavior, 4) plant knowledge, and 5) demographic characteristics. In this article, we analyzed only the data for the conjoint studies and demographic characteristics. The survey was administered from 7 to 13 Sept. 2016. Our goal was to obtain at least 100 respondents for one chronic drought state (e.g., California) and one non-drought state (e.g., Wisconsin) as based on the U.S. Drought Monitor at the time of the study to get a solid representation of both drought and non-drought conditions. All U.S. states were represented except Hawaii.

To compare respondents in different water/drought situations, we used the four categories based on whether they accurately perceived if the region in which they lived was experiencing drought as defined by Knuth et al. (2018). The four categories are based on whether they accurately perceived if the region in which they lived was experiencing drought. The four categories of drought perception were "not perceived/in real drought” (NP/R), "not perceived/not in real drought” (NP/NR), "perceived/ in real drought" $(\mathrm{P} / \mathrm{R})$, and "perceived/ not in real drought" $(\mathrm{P} / \mathrm{NR})$. Attitudes and behaviors for those who correctly perceived they were in drought were different from those who correctly perceived they were not in drought and those who incorrectly did not perceive they were in an actual drought. We compared those groups on their responses with the conjoint portion of 


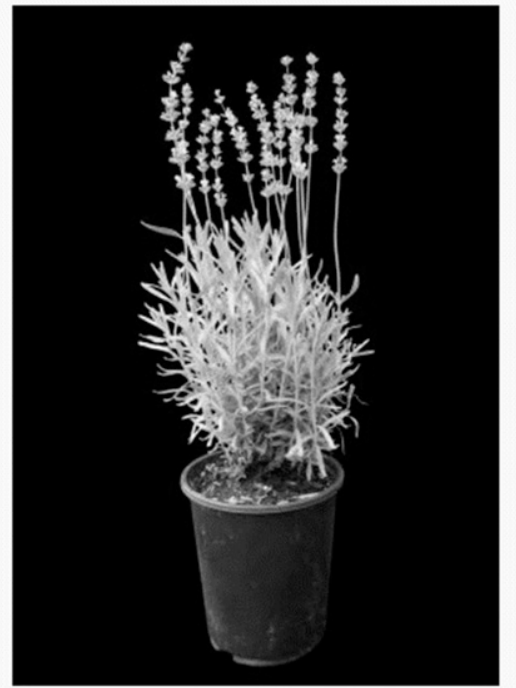

Perennial lavender, grown in the nursery with a blend of fresh and recycled water, $\$ 6.99$, requires irrigation in the landscape during the summer months to maintain acceptable health, appearance, and growth.

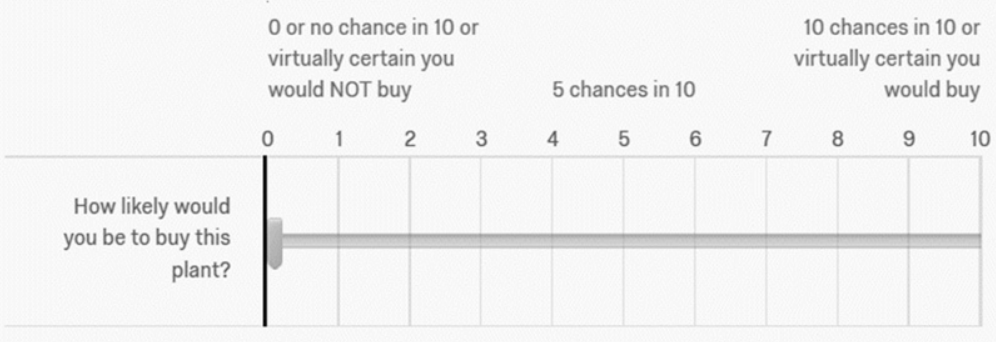

Fig. 1. An example screenshot of one conjoint image shown to 1543 subjects in an online survey pertaining to plant water source and landscape water needs.

the survey. We tested differences between utility and importance values with the TRANSREG and GLIMMIX procedures of SAS (version 9.4 for Windows; SAS Institute, Cary, NC).

\section{Results}

The survey was administered to 5769 potential participants. Subjects who agreed with the consent form and passed the four survey checks (where subjects were directed to answer in a specific manner to ensure that respondents were reading every question) totaled 1543 or $\approx 26.7 \%$. All U.S. states were represented except Hawaii, which was not deliberate, but an artifact of the sampling.

The mean age of respondents was 40 years old $( \pm 16.9$ years $)$ and respondents were predominately female $(57.8 \%)$. The mean household size was 1.2 adults and had a mean of 0.43 children for an average household size of about two people. Respondents were primarily white $(90 \%)$; followed by African American (4\%); Hispanic (3\%); Asian (2\%); and Native American, Pacific Islander, and other races $(1 \%)$. About a third (28.3\%) had earned a 4-year college degree followed by $21 \%$ of respondents who had some college education. The majority of the respondents lived in suburban areas $(59.8 \%)$ and the mean yearly household income was \$60,000-\$79,999.

Our sample population was comparable with the 2016 U.S. Population Census (U.S. Census Bureau, 2017), from 2010 to 2015, Americans were 37.8 years old and had a mean household income of $\$ 79,263$. The total U.S. population is $\approx 323,127,513$. Average household size is 2.6 people. The population is $77 \%$ white; $13.3 \%$ Black/ African American; 17.6\% Hispanic; 5.6\% Asian; and 1.4\% Native American, Pacific Islander, or other races. Nationally, 29.8\% of Americans have a bachelor's degree or higher. Females represent $50.8 \%$ of the population and the median age is 37.9 years old (U.S. Census
Bureau, 2017). However, without published variances, it is not possible to compare the samples statistically.

The national average of horticulturerelated spending in 2015 by the households participating in the $\mathrm{Na}$ tional Gardening Survey was \$401, up from \$317 in 2014 (Butterfield and Baldwin, 2016). The largest segment, Food Gardening, captured 36\% of the consumers followed by Flower Gardens at 34\%. The largest portion of the 90 million households (75\% of total U.S. households) who garden have an income of $\$ 75,000$ or more, are mostly female, are $\mathbf{5 5}$ years old and greater, and have a bachelor's degree. Twenty-eight percent of households buy their plants from home centers whereas $29 \%$ buy from mass-merchandisers. The sample frame in our study appears to be similar to that of the U.S. Census and National Gardening Association samples.

Of the total respondents, $16.4 \%$ were in the group P/R, 29.1\% were in the group NP/NR, $52.3 \%$ were classified in the group $\mathrm{NP} / \mathrm{R}$, and only $2.0 \%$ were in the group $\mathrm{P} / \mathrm{NR}$. Those in the $\mathrm{NP} / \mathrm{NR}$ were accurate in their perception that they did not experience a drought. This group may serve as a "control" or "benchmark" against which to compare the other groups. Those in the $\mathrm{P} / \mathrm{R}$ were accurate in that they perceived a drought when they were really in a drought situation. The $\mathrm{NP} / \mathrm{R}$ group is of interest because they experienced a drought but did not perceive it. Given the incorrect assessment of a perceived drought, which did not actually occur and the very small size of the $\mathrm{P} / \mathrm{NR}$ group, they were excluded from these analyses.

Demographically, the three categories were similar in the distribution of gender, number of children, number of adults, and income. However, subjects in the $\mathrm{P} / \mathrm{R}$ category were nearly 3 years older than the subjects in the NP/R category $(P=0.013)$.

Overall, $49.8 \%$ of all subjects had purchased annual plants in 2016, 42\% had purchased a vegetable transplant, $30 \%$ had purchased an herb, 30\% had purchased a perennial, 19\% had purchased a flowering shrub, 9\% had purchased a fruit tree, $7 \%$ had purchased an evergreen shrub or shade tree (Table 1), and $21 \%$ had bought an indoor flowering plant. Mean plant expenditures were $\$ 122.52$ in 2015 and were $\$ 119.07$ in 2016 
Table 1. Overall percentage of respondents purchasing 12 plant types and amount spent on plants and related supplies (excluding equipment) in 2015 and 2016 with comparisons among respondents in three drought situations/perceptions $(\mathrm{NP} / \mathrm{R}=$ in a real drought, but drought not perceived; NP $/ \mathrm{NR}=$ correctly perceived no real drought; and $\mathrm{P} / \mathrm{R}=\mathrm{correctly}$ perceived being in a real drought). Utility and importance values, and data analyses were generated using the TRANSREG and GLIMMIX procedures of SAS (version 9.4 for Windows; SAS Institute) at $P \leq \mathbf{0 . 0 5}$.

\begin{tabular}{|c|c|c|c|c|}
\hline & $\begin{array}{c}\text { Total, } \\
n=1,535 \\
\end{array}$ & $\begin{array}{c}\mathrm{NP} / \mathrm{R}(\%) \\
{[\text { mean }(\mathrm{SE})], n=\mathbf{8 0 3}}\end{array}$ & $\begin{array}{c}\mathrm{NP} / \mathrm{NR}(\%) \\
{[\operatorname{mean}(\mathrm{SE})], n=252}\end{array}$ & $\begin{array}{c}\mathrm{P} / \mathrm{R}(\%) \\
{[\operatorname{mean}(\mathrm{SE})], n=449}\end{array}$ \\
\hline \multicolumn{5}{|l|}{ Plant type } \\
\hline Vegetable & $42(0.013)$ & $40(0.017)$ & $45(0.031)$ & $42(0.023)$ \\
\hline Herb & $30(0.012)$ & $32(0.016)$ & $25(0.027)$ & $31(0.022)$ \\
\hline Perennial & $30(0.012)$ & $30(0.016)$ & $31(0.029)$ & $29(0.022)$ \\
\hline Fruit tree & $9(0.007)$ & $9(0.010)$ & $9(0.018)$ & $10(0.014)$ \\
\hline Evergreen tree & $7(0.007)$ & $7 \mathrm{~b}(0.009)$ & $4 \mathrm{c}(0.012)$ & $8 \mathrm{~b}(0.013)$ \\
\hline Shade tree & $8(0.007)$ & $6(0.007)$ & $7(0.016)$ & $10(0.014)$ \\
\hline Indoor flowering plant & $21(0.010)$ & $23 \mathrm{~b}(0.015)$ & $16 c(0.023)$ & $20 \mathrm{~b}(0.019)$ \\
\hline Indoor foliage plant & $11(0.008)$ & $11(0.011)$ & $11(0.310)$ & $12(0.015)$ \\
\hline
\end{tabular}

(Table 1). The percentage of subjects in the three categories who purchased evergreen shrubs, evergreen trees, and indoor flowering plants differed in this study. Half as many subjects in the $\mathrm{NP} / \mathrm{NR}$ purchased an evergreen tree compared with those in the $\mathrm{P} / \mathrm{R}$ or $\mathrm{NP} / \mathrm{R}$ categories. A higher percentage of the $\mathrm{P} / \mathrm{R}$ respondents purchased evergreen trees compared with respondents in the NP/R or NR/NP categories. More individuals in the $\mathrm{NP} / \mathrm{R}$ and $\mathrm{P} / \mathrm{R}$ group purchased indoor flowering plants compared with the other group. They also spent more on plants and related gardening supplies, excluding equipment in 2015.

Next, we analyzed the conjoint design for perennials, both overall and by drought perception group (Table 2). Price and water use in the landscape were statistically similar. The perennial verbena was preferred over the english lavender and the coral bells were the least preferred. Plants grown with fresh water were preferred over plants grown with recycled water and the blend of fresh and recycled water was the least preferred. In terms of water use in the landscape, respondents most preferred plants that required irrigation but only for the first season, and following economic logic, lower prices were preferred to higher prices.

There were several differences between the drought perception/ realization groups. The water use in the landscape attribute was slightly more important for the $\mathrm{NP} / \mathrm{NR}$ group compared with the other two groups, both of which had experienced a real drought. In addition, the utility score for "grown in the nursery with fresh water" was lower for the $\mathrm{NP} / \mathrm{NR}$ group compared with the $\mathrm{NP} / \mathrm{R}$ group. We also found that the NP/NR group valued (had a lower utility score) "requires irrigation in the landscape but only for the first season to help the plant become established" less compared with the NP/R group.

For woody perennials overall, plant genus was the most important attribute, followed by price and water use in production, and least the important was water use in the landscape (Table 3 ). Redbud was the most preferred plant, followed by goldenrain tree and fragrant sumac. Grown with fresh water or grown with a blend of fresh and recycled water were preferred over grown with recycled water. Requiring irrigation until establishment was preferred over requiring irrigation for most seasons. Again, following economic logic, lower prices were preferred to higher prices. In comparing the groups, only one difference was observed.

That is, plant genus was more important for $\mathrm{NP} / \mathrm{R}$ compared with $\mathrm{NP} / \mathrm{NR}$.

\section{Discussion}

For both herbaceous perennials and woody perennials, plant genus was the most important factor. This was consistent with much of the prior literature where the plant type was the primary factor in the decision to purchase or likelihood to buy rating (Behe et al., 2005a, 2005b, 2010, 2013, 2016; Getter and Behe, 2013; Mason et al., 2008; Rihn et al., 2015, 2016; Yue et al., 2010). The novel contribution from this study is that water source during production and water use while in the landscape were at least as important as the price. This finding suggests that there may be some benefit to describing both water source and water needs for plants expected to last more than one season (e.g., herbaceous perennials and woody perennials) in point of purchase information. St. Hilaire et al. (2008) showed that educational programs regarding public water conservation influenced landscape choices from present landscape plants to more water conserving landscape plants. Promotion of low water use plants and the use of recycled water in plant production of those plants may become marketable benefits.

Consumers placed greater relative importance on water source during production over water use in the landscape for both the herbaceous and woody perennials included in this study. They preferred fresh water over recycled water and least preferred a blend of fresh with recycled water for perennials and recycled water used for woody perennials. In addition, the 


\section{Production and Marketing Reports}

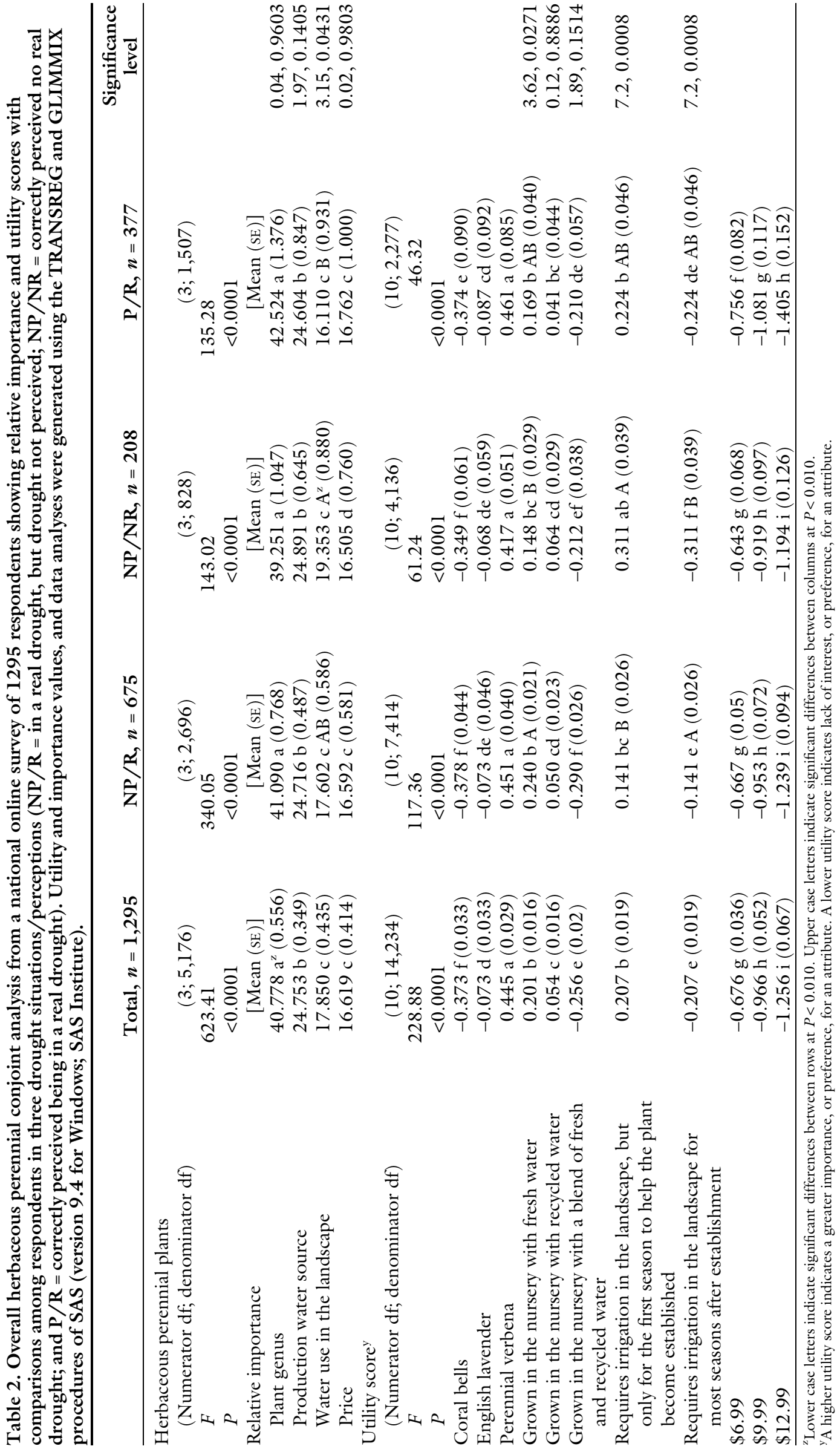




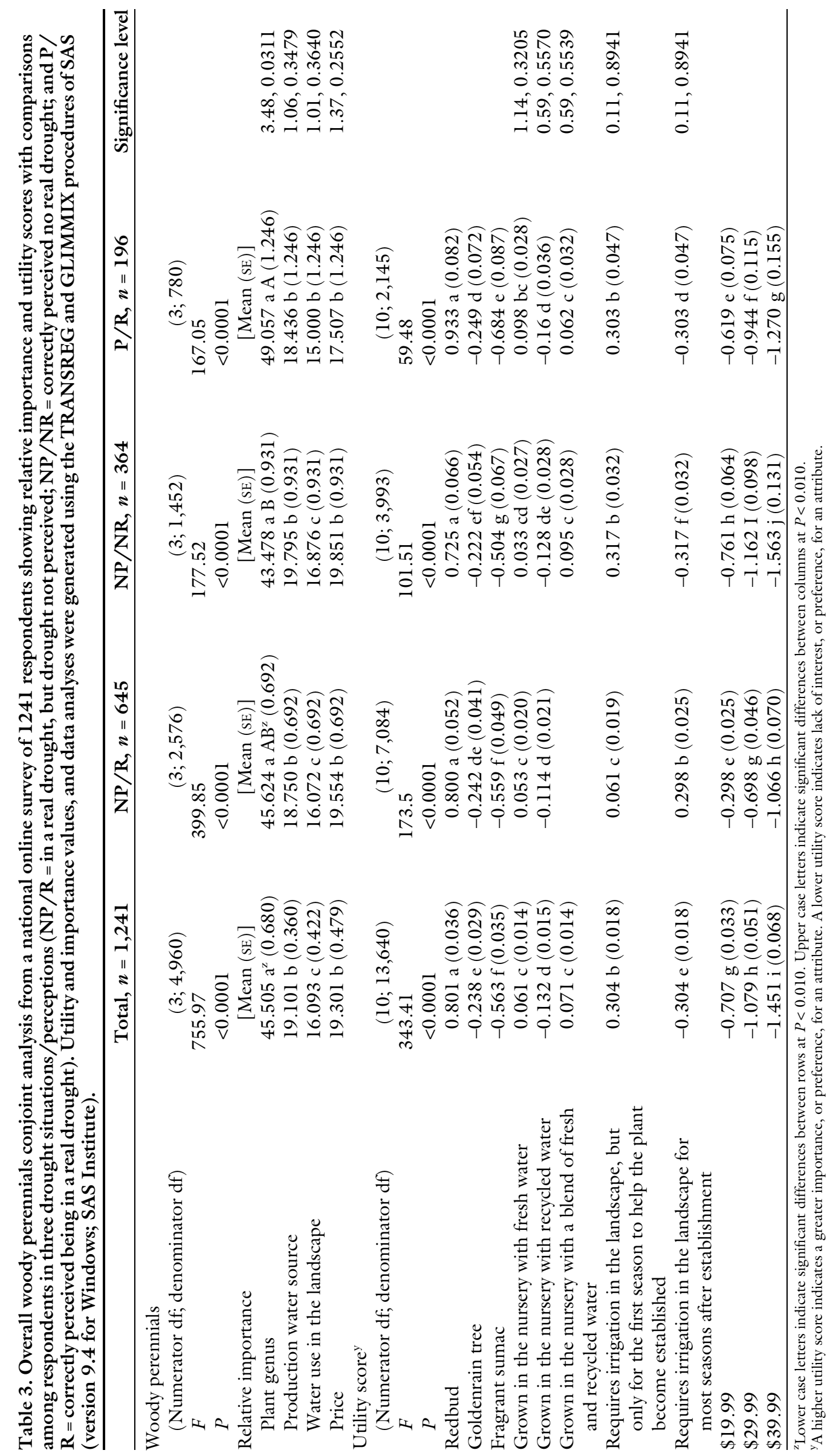


$\mathrm{NP} / \mathrm{R}$ group, who incorrectly assessed that they were not in drought when they actually were, placed a higher value on nursery plants grown with fresh water compared with those who were actually not in drought and did not perceive one $(\mathrm{NP} / \mathrm{NR}$, the comparison group). This finding parallels what St. Hilaire et al. (2008) found in that, despite scant evidence of the increased risk of disease, recycled water has become more popular only among water conservationists who seek to achieve more efficient ways to use water.

Hurd (2006) suggested that with a focus on consumer attitudes, changes in landscape plant selection could reduce overall water use and reduce future water demand. The attitude that recycled water was not as valuable (lower utility score), especially for the $\mathrm{NP} / \mathrm{R}$ group shows a great need for education. Consistent with St. Hilaire et al. (2008) and Yanko (1992), subjects in this study may have preferred fresh water because of concerns about or lack of information regarding the safety of recycled water (gray water). Clearly, this is a point for future education, especially for nurseries striving to conserve water resources in other work has shown that sustainability concerns from consumers often translate into substantial willingness to pay price premiums (Behe et al., 2010, 2013; Getter and Behe, 2013; Khachatryan et al., 2016). The use of biodegradable containers, e.g., translates into higher price premiums for ornamental products (Yue et al., 2010). St. Hilaire et al. (2008) showed that when communities favorably viewed recycled water as a valuable resource if they understood their water situation, they substantially reduced water use in New Mexico communities. Many of our subjects appeared to be unlike those in St. Hilaire et al. (2008) in that they discounted the importance of recycled water and preferred to use fresh water. Perhaps, the use of recycled water could be more socially acceptable if it were marketed as a means to produce a high-quality product while conserving an important natural resource on the farm or production site.

Plant water needs in the landscape were less important than the water source for those respondents of this study. Requiring irrigation for one season for plant establishment was clearly preferred over requiring irrigation for most seasons after establishment for both herbaceous perennials and woody perennials. However, we observed some differences in drought perception/realization group for landscape water use for perennials. The comparison group $\mathrm{NP} / \mathrm{NR}$ placed a higher value on the requirement for irrigation during the first season when compared with the NP/R group. These findings suggest that, with some additional education about the water use needs of landscape plants, the value for plants requiring irrigation in only the first season might be improved. Marketing the water needs of plants may become a more valuable attribute.

We found few differences between the three drought perception groups, but they appear to be important differences. Because $30 \%$ of the respondents had purchased perennials, whereas only $7 \%$ to $9 \%$ had purchased some type of tree (e.g., evergreen, fruit, or shade), the low purchase rate of trees may be one reason for finding few differences.

\section{Conclusions}

The findings from this study, for the first time, combine production water source and landscape water use and show that water source in production and water use needs in the landscape are relatively similar to price in terms of relative importance. This is helpful information for the green industry in that efforts to communicate water source and water needs may be favorably received by consumers. Hall and Dickson (2011) reported that consumers "have, however, exhibited a willingness to purchase and, in some cases, pay a premium for products and services that enhance their quality of life in terms of social well-being, physical well-being, spiritual well-being, and environmental well-being." Kotler and Keller (2016) would argue that consumers buy benefits, not product features or attributes. Plant water use and water source for production could potentially be marketed to show the consumer environmental benefits.

\section{Literature cited}

Al-Jayyousi, O.R. 2003. Greywater reuse: Towards sustainable water management. Desalination 156(1):181-192.

Beal, C.D., R.A. Stewart, and K. Fielding. 2013. A novel mixed method smart metering approach to reconciling differences between perceived and actual residential end use water consumption. J. Clean. Prod. 60:116-128.

Behe, B.K., B. Campbell, J. Dennis, C. Hall, R. Lopez, and C. Yue. 2010. Gardening consumer segments vary in ecopractices. HortScience 45:1475-1479.

Behe, B.K., B.L. Campbell, C.R. Hall, H. Khachatryan, J.H. Dennis, and C. Yue. 2013. Consumer preferences for local and sustainable plant production characteristics. HortScience 48:209-215.

Behe, B., J. Hardy, S. Barton, J. Brooker, T. Fernandez, C. Hall, J. Hicks, R. Hinson, P. Knight, R. McNiel, T. Page, B. Rowe, C. Safley, and R. Schutzki. 2005a. Landscape plant material, size, and design sophistication increase perceived home value. J. Environ. Hort. 23(3):127-133.

Behe, B.K., P.T. Huddleston, and L. Sage. 2016. Age cohort influences brand recognition, awareness, likelihood to buy vegetable herb transplants. HortScience 51:145-151.

Behe, B.K., R.M. Walden, M. Duck, B. Cregg, K. Kelley, and R.D. Lineberger. 2005 b. Consumer preferences for and cost of production of tabletop Christmas trees. HortScience 40:409-412.

Butterfield, B. and I. Baldwin. 2016. National gardening survey. Natl. Gardening Assn., Williston, VT.

Cabrera, R.I., K.L. Wagner, and B. Wherley. 2013. An evaluation of urban landscape water use in Texas. Tex. Water J. 4(2):14-27.

California Department of Water Resources. 2004. Water facts no. 23: Water recycling. 17 Nov. 2017. <http://www.water.ca.gov/ pubs/conservation/water_facts_no._23_ water_recycling/waterfact23.pdfs.

Chrzan, K. and B. Orme. 2000. An overview and comparison of design strategies for choice-based conjoint analysis. 10 Dec. 2017. <http://www.sawtoothsoftware. com/download/techpap/2000Proceedings. pdf\#page $=175>$.

Cobanoglu, C., B. Warde, and P.J. Moreo. 2001. A comparison of mail, fax and websurvey methods. Intl. J. Mktg. Res. $43(4): 441-452$.

Costello, L.R. and K.S. Jones. 2014. WUCOLS IV: Water use classification of landscape species. 11 Dec. 2016. <http:// ucanr.edu/sites/WUCOLS/12/11/16>.

Dillman, D., J. Smyth, and L. Christian. 2009. Internet, mail, and mixed-mode surveys: The tailored design method. Wiley, Hoboken, NJ.

Eriksson, E., K. Auffarth, M. Henze, and A. Ledin. 2002. Characteristics of grey wastewater. Urban Water 4(1):85-104. 
Fan, Y., L. McCann, and H. Qin. 2017. Households' adoption of drought tolerant plants: An adaptation to climate change? J. Agr. Res. Econ. 42(2):236-254.

Getter, K.L. and B.K. Behe. 2013. Consumer willingness to purchase Impatiens walleriana alternatives. HortScience 48:13701377.

Gilg, A. and S. Barr. 2006. Behavioral attitudes towards water saving? Evidence from a study of environmental actions. Ecol. Econ. 57(3):400-414.

Gregory, G.D. and M.D. Leo. 2003. Repeated behavior and environmental psychology: The role of personal involvement and habit formation in explaining water consumption. J. Appl. Soc. Psychol. 33(6):1261-1296.

Hall, C.R., B. Campbell, B. Behe, C. Yue, J. Dennis, and R. Lopez. 2010. The appeal of biodegradable packaging to floral consumers. HortScience 45:583-591.

Hall, C.R. and M.W. Dickson. 2011. Economic, environmental, and health/ well-being benefits associated with green industry products and services: A review. J. Environ. Hort. 29(2):96-103.

Hayden, L., M.L. Cadenasso, D. Haver, and L.R. Oki. 2015. Residential landscape aesthetics and water conservation best management practices: Homeowner perceptions and preferences. Landsc. Urban Plan. 144:1-9

Hurd, B.H. 2006. Water conservation and residential landscapes: Household preferences, household choices. J. Agr. Res. Econ. 31(2):173-192.

Jorgensen, B., M. Graymore, and K. O'Toole. 2009. Household water use behavior: An integrated model. J. Environ. Mgt. 91(1):227-236.

Khachatryan, H., D.H. Suh, G. Zhou, and M. Dukes. 2016. Sustainable urban landscaping: Consumer preferences and willingness to pay for turfgrass fertilizers. Can. J. Agr. Econ. 65(3):385-407.

Kotler, P.T. and K.L. Keller. 2016. Marketing management. 15th ed. Pearson Prentice Hall, Upper Saddle River, NJ.

Knuth, M., B.K. Behe, C.R. Hall, P.T. Huddleston, and R.T. Fernandez. 2018. Consumer perceptions, attitudes, and purchase behavior with landscape plants during real and perceived drought periods. HortScience 53:49-54.

Mason, S., T. Starman, R.D. Lineberger, and B.K. Behe. 2008. Consumer preferences for price, color harmony and care information of container gardens. HortScience 43:380-384.

McCullough, D. 1998. Web-based market research: The dawning of a new age. Direct Mktg. 61(9):36-38.

Rihn, A., H. Khachatryan, B. Campbell, B. Behe, and C. Hall. 2015. Consumer response to novel indoor foliage plant attributes: Evidence from a conjoint experiment and gaze analysis. HortScience 50:1524 1530 .

Rihn, A., H. Khachatryan, B. Campbell, C. Hall, and B. Behe. 2016. Consumer preferences for organic production methods and origin promotions on ornamental plants: Evidence from eye-tracking experiments. Agr. Econ. 47(6):599-608.

Seyranian, V., G.M. Sinatra, and M.S. Polikoff. 2015. Comparing communication strategies for reducing residential water consumption. J. Environ. Psychol. $41(3): 81-90$.

Somerville, C. and J. Briscoe. 2001. Genetic engineering and water. Science $292(5525): 2217$.
Spinti, J.E., R. St. Hilaire, and D. VanLeeuwen. 2004. Balancing landscape preferences and water conservation in a desert community. HortTechnology $14: 72-77$.

Springer, A.C. 2011. Creating water conscious communities: An examination of household water conservation in a decade of drought. Univ. Ariz., Tucson, AZ, PhD Diss.

St. Hilaire, R., M.A. Arnold, D.C. Wilkerson, D.A. Devitt, B.H. Hurd, B.J. Lesikar, and D.R. Pittenger. 2008. Efficient water use in residential urban landscapes. HortScience 43:2081-2092.

Syme, G.J., C. Seligman, and J.F. Thomas. 1991. Predicting water consumption from homeowners' attitudes. J. Environ. Syst. 20(2):157-168.

Syme, G.J., Q. Shao, M. Po, and E. Campbell. 2004. Predicting and understanding home garden water use. Landsc. Urban Plan. 68(1):121-128.

U.S. Census Bureau. 2017. American FactFinder. 8 Feb. 2017. <https:// factfinder.census.gov/faces/tableservices/ jsf/pages/productview.xhtml?pid=ACS 15_5YR_DP05\&src $=p t>$.

Western Municipal Water District. 2017. Gray water. 8 Feb. 2017. <http://www. wmwd.com $/ 417 /$ Gray-Water $>$.

Yanko, W. 1992. Analysis of 10 years of virus monitoring data from Los Angeles county treatment plants meeting California wastewater reclamation criteria. Water Environ. Res. 65(3):221-226.

Yue, C., C.R. Hall, B.K. Behe, B.L. Campbell, R.G. Lopez, and J.H. Dennis. 2010. Investigating consumer preference for biodegradable containers. J. Environ. Hort. 28(4):239-243. 